\title{
Washed Out: Policy and Practical Considerations Affecting Return after Hurricane Katrina and Superstorm Sandy
}

\author{
Nicholas S. Bryner (corresponding author) \\ Emmett Institute on Climate Change and the Environment, \\ University of California-Los Angeles School of Law \\ 2000 H Street, NW, Washington, DC 20052, United States \\ E-mail: bryner@law.ucla.edu
}

\begin{abstract}
Marisa Garcia-Lozano
Latin America \& the Caribbean Urban and Disaster Risk Management

The World Bank

Carl Bruch

International Programs, Environmental Law Institute
\end{abstract}

Received: January 10, 2017 Accepted: February 5, 2017 Published: February 28, 2017

doi:10.5296/jad.v3i1.10590 URL: http://dx.doi.org/10.5296/jad.v3i1.10590

\begin{abstract}
The destructive impacts of Hurricane Katrina and Superstorm Sandy displaced large numbers of people. While some families were able to return home soon after the disasters, others struggled to do so and remained displaced for extended periods of time. Although much attention has been paid to the immediate response to natural disasters, research on policies and practices regarding long-term return migration has been largely overlooked. This article presents an overview of recent literature that addresses factors affecting displaced individuals' decision to return home or relocate following these two disasters. It discusses five major factors influencing individual and household decisions regarding whether to return home, relocate, or remain in limbo if unable to achieve either. These include: (1) habitability
\end{abstract}




\section{Macrothink}

Journal of Asian Development

ISSN 2377-9594 2017, Vol. 3, No. 1

of homes; (2) affordability of housing; (3) financial burdens; (4) slow restoration of public services and facilities; and (5) sense of place and identity. The article then assesses the types of policies that have been used with varying goals - promoting, discouraging, and, in some cases, prohibiting return. It presents four examples of policy tools that have influenced post-disaster return or relocation after Hurricane Katrina and Superstorm Sandy: (1) tax policies; (2) buyouts; (3) changes to building codes; and (4) revisions to the U.S. National Flood Insurance Program. The article concludes that a better understanding of factors affecting displaced persons can help policymakers meet their objectives of encouraging or inhibiting return to a specific site after a disaster.

Keywords: Natural disasters, return migration, policy, displacement, Hurricane Katrina, Superstorm Sandy, disaster recovery 


\section{Introduction}

Hurricane Katrina, the costliest hurricane in U.S. history, hit New Orleans over a decade ago. Long after the immediate effects of the disaster had subsided, however, disruptive impacts continued for families and communities, as they struggled to return to affected areas. In New Orleans, as in other disaster-struck cities, many returned or moved on, while others remained in limbo, with "nothing to go back to" or no resources to rebuild a previous way of life (Dewan, 2007).

While there is a vibrant policy discussion about disaster risk reduction and response to natural disasters, there has been little scholarly research or policy dialogue on the longer-term dynamics, policy objectives, or options and practices regarding return migration after a catastrophic disaster. These questions, however, loom large for future policymaking. Due to climate change, the frequency and intensity of extreme weather events are expected to increase, and with the world's population continuing to grow through the first half of the $21^{\text {st }}$ century, increased concentration of population in urban centers and coastlines means that disasters - weather induced and otherwise-will likely displace even greater numbers of people.

Policymakers' objectives for post-disaster return can and should vary, depending on the circumstances. Strategic decisions regarding whether to encourage return or relocation should be made carefully, taking into account the various social, cultural, economic, and environmental impacts of post-disaster response and rebuilding, as well as the likelihood of repeated disasters. However, even after decision-makers have set priorities or objectives for post-disaster return - whether and where to promote return - policy responses after a disaster often face political, social, and financial challenges and limitations. Given these constraints, a better understanding of what factors are most likely to affect displaced individuals' choices can help policymakers tailor the policies they employ to meet their objectives more effectively.

This article begins with a review of factors, described in recent literature, that affect displaced persons' decisions with regard to whether, when, and how to return or relocate after a disaster. Studies of people displaced by Hurricane Katrina and Superstorm Sandy show that housing concerns are most prominent, although other factors can also be significant, including concerns about public services, financial constraints, and personal or social attachments. The article then seeks to categorize and assess the types of policy choices and tools that have been used to influence household decisions after these disasters - either toward or against return. In light of the experiences following Hurricane Katrina and Superstorm Sandy, policymakers should consider whether the establishment of clear objectives and coordinated policies regarding return or relocation, taking into account the factors affecting individual decisions, can limit the extent to which displaced people remain unsettled in the longer term.

\section{Factors Affecting Return}

Following the disasters in the U.S. Gulf Coast and Northeastern coastline, researchers identified a number of factors that affected individual and household choices regarding return 


\section{MInstitute ${ }^{\text {Macrothink }}$}

or relocation and the ability of displaced people to return home. The most significant factors relate to housing concerns - habitability, affordability, and availability of funding to assist with rebuilding or repair. Other salient factors include access to public services and facilities, sense of place and identity, and concerns regarding future disasters, employment, and additional stresses associated with rebuilding and recovery. This section reviews these factors and their impact on the duration of displacement of those affected by Hurricane Katrina and Superstorm Sandy.

\subsection{Hurricane Katrina}

On August 29, 2005, Hurricane Katrina made landfall along the Louisiana-Mississippi border as a Category 3 storm (Saffir-Simpson scale), with sustained winds averaging over 120 miles per hour. In preparation for this hurricane, the states of Alabama, Mississippi, and Louisiana issued mandatory evacuations a day earlier. The evacuation order was the first ever issued for New Orleans, the largest city in the area. The storm displaced an estimated 1.5 million people, 75 percent of whom were living in Louisiana (Groen \& Polivka, 2008). (Note 1)

The Federal Emergency Management Agency (FEMA) classified Katrina as "the single most catastrophic natural disaster in U.S. history" (FEMA, 2006a). To date, it remains the costliest hurricane in the country's history, having inflicted more than US\$125 billion in economic losses (FEMA, 2006b). Federal recovery funding amounted to US $\$ 120.5$ billion, with $\$ 75$ billion allocated to emergency relief (Plyer, 2016). The number of fatalities reached 1,833, placing Katrina third on the list of deadliest hurricanes in U.S. history.

According to Falk, Hunt, and Hunt (2006), the hurricane resulted in the largest displacement of people in the United States since the Dust Bowl of the 1930s. Many people returned home within days, but up to 600,000 households remained displaced one month after the storm (Plyer, 2016). According to the Current Population Survey (CPS), by October 2006 (one year after Katrina), 64.9 percent of evacuees from Louisiana, Mississippi, and Alabama had returned to their former residences, and 72.5 percent had returned to their original counties (Groen \& Polivka, 2008). Alabama experienced the highest return rate, with 94.4 percent of evacuees having returned to their original counties, which stands in contrast with 68 percent in Louisiana.

Just as return was not spread evenly across the states affected by the hurricane, return also varied widely by neighborhood within New Orleans itself. When 53 levees surrounding the city were breached, 80 percent of the city became covered by water. The most severe property damages were registered in the wards and districts of New Orleans' East, Lower Ninth Ward, and Village de l'Est, in which up to 95 percent of housing units were destroyed (Kamel, 2012). Eleven months after Katrina, the city's population dropped to an estimated 230,000, barely half its pre-storm population of 454,863 residents (Sastry, 2009). The Times-Picayune reported more than 100,000 New Orleanians were still displaced five years after the storm, and the number was still in the thousands ten years after the storm (McClendon, 2015; Tilove, 2010).

Although many who did not return after Katrina decided to relocate permanently, for others, 
the experience of displacement lingered for years. By May 2007, nearly two years after the storm, more than 30,000 displaced families were still living in apartments paid for by FEMA, and around 13,000 other families remained in trailer or mobile home parks (Dewan, 2007). A working paper by the U.S. Census Bureau's Social, Economic and Housing Statistics Division found that as of 2009, an estimated 31,500 households, or 7 percent of all households in the New Orleans metro area that same year, did not view themselves as permanently settled, but rather in a "still in transition" phase (Geaghan, 2011, 7). These long-term displaced residents were concentrated mostly in the neighboring southern states of Texas, Georgia, Alabama, Mississippi, and Florida. Other places in Louisiana-outside the New Orleans metropolitan area-accounted for about one quarter of displaced households (Sastry \& Gregory, 2014).

In addition to changes in overall population numbers, New Orleans also underwent changes in racial composition. A number of authors noted that African-American and low-income communities lived in areas at greater risk for flooding, and suffered the most serious property damage from the hurricane (Chamlee-Wright \& Storr, 2009; Fussell, Sastry, \& VanLandingham, 2010; Groen \& Polivka, 2010; Paxson \& Rouse, 2008). As a result, when comparing the city's population from 2000 to 2013, the African-American population decreased from 67 to less than 60 percent, while the Caucasian population increased from 26 to over 30 percent, even as the absolute numbers for both groups decreased (Shrinath, Mack \& Plyer, 2014).

Overall, studies showed differentiated rates of return according to age, race, education, employment status, and housing condition. Sastry (2009) noted that "[i]ndividuals who are older, White, college-educated, employed or retired, with a habitable home were more likely to return to New Orleans in the first year after Hurricane Katrina struck" (7). On the other hand, "children, and young adults, Blacks, the less educated, the unemployed, and those without a habitable dwelling" constituted a disproportionate share of those who remained displaced (Sastry, 2009, 8). Additionally, Kamel (2012) explains that areas with large apartment buildings and rental units, especially affordable housing developments, were among those with the lowest repopulation rates, suggesting a negative correlation between poverty and likelihood of return.

Whether people had the ability to choose to return home or relocate to a new place after Hurricane Katrina, and what they ultimately decided, depended on a combination of personal and circumstantial factors. Studies (Chamlee-Wright \& Storr 2009; Groen \& Polivka, 2010; Finger, 2011; Henry, 2013; Landry, Bin, Hindsley, Whitehead, \& Wilson, 2007; Paxson \& Rouse, 2008; Sastry, 2009) discussing reasons that affected an individual's decision and ability to return or relocate shed light on why some, years later, were still unable to achieve either, thus remaining in a "grim limbo of exile" (Dewan, 2007).

Similarities in the narratives of those who were able to return and those who remained indefinitely displaced were often correlated with emotional attachment to the city of New Orleans and to the lifestyle it offered. According to Morrice (2013), Katrina evacuees' strong desire to return "relates to their nostalgic connection to the city and idealistic perception [of] 


\section{MInstitute ${ }^{\text {Mink }}$}

returning 'home', to a place of safety and familiarity" (Morrice, 2013, 38). This suggests a significant role for sense of place and community identity in individuals' decision-making process. The decision to return was also influenced by hostility faced in host cities and a sense of optimism of recovery process in Katrina-hit locations.

There were also practical circumstances that oriented displaced people toward return. For example, homeownership was determinative for many evacuees. A study by Landry et al. (2007) shows that homeownership increased the probability of return by 21 percent. However, homeownership was negatively correlated with return when homes were uninhabitable or located in high-damage or highly flooded areas (Groen \& Polivka, 2010; Sastry, 2009).

The reasons attributed to longer displacement or permanent relocation are diverse. Broadly, they can be grouped into four categories of explanations: housing issues, public services shortages, financial constraints, and preference for other locations.

Studies show that flood exposure and housing damage are at the top of the list of factors affecting residents' decision and ability to return (Fussell et al., 2010; Paxon \& Rouse, 2008). Only 30 percent of residents whose homes were entirely destroyed returned to New Orleans within the first 14 months after the hurricane, compared to 81 percent of residents with damaged but habitable homes (Fussell et al., 2010). Displaced residents were also faced with a lack of affordable housing in the city. House prices rose 50 percent from 2004 to 2006 (Vigdor, 2008), while rent costs surged by 40 percent in the four years after the hurricane (Lewis, 2013). Minority and low-income groups-less likely to be homeowners-were disproportionately affected, as much of the affordable housing in New Orleans was destroyed or badly damaged, and never entirely rebuilt. Amnesty International (2010) reported that only 38 percent of the 82,000 lost rental units in the state of Louisiana had been rebuilt by 2008 .

Demolition of public housing developments, home to more than 5,000 families before Katrina, also impeded evacuees' return. Despite facing strong opposition, the Department of Housing and Urban Development demolished 4,500 units at the four largest public housing complexes, known as the "Big Four," displacing approximately 20,000 residents (Amnesty International, 2010; Dewan, 2007). Homeowners encountered numerous problems in utilizing government-funded programs to aid in rebuilding their homes, including fund mismanagement, inadequate and delayed payment of grants, changes of rules in building procedures and eligibility criteria, and preferential treatment, among many other obstacles that extended their displacement (Dart, 2014; Kamel, 2012; Winerip, 2013).

Desire and ability to return were also constrained by the slow reinstitution of public services and facilities, such as water, electricity, schools, hospitals, and nursing homes. A year after the hurricane, a number of neighborhoods in the Ninth Ward lacked electrical and water services. Schools were also missing. A study of low-income parents-mostly African American women - enrolled in a community college prior to Hurricane Katrina found that respondents with a greater number of children were less likely to return (Paxson \& Rouse, 2008). The authors suggested schools' slow reopening as an explanation. In an analysis of the 2010 U.S. Census of Louisiana, Beveridge revealed that New Orleans had 56,193 fewer children than before Katrina, accounting for a 44 percent decrease (Robertson, 2011). 
Financial constraints also prevented displaced individuals from returning. High costs of moving back, financial instability, and employment loss hindered individuals' ability to return home (Groen \& Polivka, 2010; Landry et al., 2007; Morrice, 2013). A total of 250,000 people across the region lost their jobs between mid-August and mid-November 2005 (Landry et al., 2007). Low-income families were particularly affected. The percentage of residents with annual incomes lower than US\$15,000 fell from 19.3 percent before Hurricane Katrina to 12.6 percent in the second year after the disaster, a demographic shift suggesting that low-income displaced families were more likely to relocate permanently, and less able to return (Groen \& Polivka, 2010).

Affected individuals who chose to relocate permanently, rather than return home, commonly cited the desire to being a new life in host cities. For instance, a survey of evacuees found 47 percent preferred Houston over their home city of New Orleans because they had found "better schools, better jobs, an improved quality of life, lower crime, better housing and/or better healthcare (Chamlee-Wright \& Storr, 2009, 628). Sastry and Gregory (2014) add to this list better neighborhood environments and amenities in new locations. The other reason the affected individuals chose to relocate was a shared sense of fear of future natural catastrophes.

\subsection{Superstorm Sandy}

Superstorm Sandy set a record as the largest tropical storm in the history of the Atlantic basin and the second costliest in U.S. history, with economic losses of over US\$67 billion. It affected 24 U.S. states, inflicting the most damage and casualties in New Jersey and New York. The natural disaster left a death toll of at least 159 in the United States (National Centers for Environmental Information, 2016). Despite downgrading from a hurricane to a post-tropical cyclone at landfall near Brigantine, New Jersey, on October 29, 2012, Sandy's enormity generated a massive storm surge, leading to catastrophic damage in New York and the surrounding area. Several states declared a state of emergency, with forced or voluntary evacuation orders in various coastal areas.

No official estimates have been released on the number of people displaced by Sandy, neither in the aftermath of the disaster nor as of today. However, the International Displacement Monitoring Centre (IDMC) calculated a displaced population of 776,000 immediately after the storm (IDMC, 2012). Approximately three years later, IDMC estimated 53,500 people were still displaced (IDMC, 2015), while other sources similarly reported a figure ranging in the tens of thousands one year after the storm (Kusisto \& Dawsey, 2014; McGeehan \& Palmer, 2013; Parry, 2013). Thousands of people whose houses were seriously damaged were relocated to rental units, hotels, motels, and trailers that were mostly paid for by federal aid programs covering temporary housing assistance, and on a smaller scale by non-profit groups. Yet others moved in with family members or remained in evacuation centers or homeless shelters.

One week after the disaster, the federal government approved over US\$203 million in housing assistance for more than 45,000 families (Barron, Lipton \& Rivera, 2012). The money would be used to cover temporary lodging expenses and home repairs. The largest 
sources of federal aid to storm victims were the Federal Emergency Management Agency (FEMA) and the Department of Housing and Urban Development (HUD). FEMA provided $\$ 1.4$ billion in direct aid, and HUD distributed \$16 billion to state and local agencies to assist in fixing homes (McGeehan \& Palmer, 2013). More than 260,000 households registered for FEMA assistance, 58 percent of whom were homeowners and 42 percent renters (Kalet, 2013).

Similar to the recovery efforts following Hurricane Katrina, states were slow to disburse money, leaving many displaced for a longer period of time. In New Jersey, for example, only around one-quarter of HUD money had been distributed two years after Sandy hit- $\$ 802$ million out of the promised \$3.26 billion as of September 2014 (Hanna \& Seidman, 2014). Aid delivery was gridlocked for reasons similar to those that hindered post-Katrina relief. The federal government was trying to avoid fraudulent and poorly planned expenses that had been problematic after Katrina. Residents seeking aid criticized "red tape" restrictions on the timely transfer of funds, including requirements for environmental reviews for damaged properties, as well as rigid and changing building requirements intended to improve the resilience of homes. These challenges notwithstanding, HUD managed to allocate half of its aid to lower income families, meeting a requirement of the Department (Kusisto \& Dawsey, 2014).

Renters struggled to find places to live after the storm. Channeling funds to individuals paying rent proved difficult, as they were often harder to track and in some cases lacked lease agreements to verify their living situation. Efforts such as the Landlord Incentive Program in New Jersey aimed to fill the gap. The initiative offered US $\$ 40$ million in total to landlords who rented their units as affordable housing (Kalet, 2013). Another group experiencing problems consisted of poor families who were placed indefinitely in hotel rooms and had no home to return to or were unable to qualify for available apartments due to their low-income status. The New York City's Temporary Disasters Assistance Program (TDAP) provided households a rent subsidy to afford "emergency moves," in which households pay 30 percent of their income toward rent, and receive a subsidy to cover additional housing expenses for a period of two years (Baussan \& Peterson, 2015).

People chose to return home or to relocate after the storm for a variety of reasons. Shortcomings in rebuilding programs were the primary barrier preventing people from returning. Displaced families that wished to return home encountered delays in rebuilding. For example, New Jersey created the large rebuilding program, Rehabilitation, Reconstruction, Elevation and Mitigation (RREM), to provide funds to homeowners to restore their homes. However, more than two and a half years after the storm, only around 1,000 of the approximately 8,300 homeowners registered in the RREM had completed construction and had been able to return home (Luedekke, 2015). In February 2015, civil society organizations estimated that there were 15,000 families still displaced from Sandy waiting to rebuild, 2,000 of which had withdrawn from the program as a consequence of dwindling hope (Fair Share Housing Center, Latino Action Network and NAACP New Jersey State Conference, 2015). 
A survey showed that people experienced high levels of stress due to challenges in rebuilding and recovery, threat of future hazards, and filing insurance claims, in that respective order (Bukvic, Smith, \& Zhang, 2015). As a result, moving somewhere else proved to be less stressful for some. Bukvic, Smith, \& Zhang (2015) suggested this may be because some people considered relocation "less disturbing than dealing with the future risks and recovery challenges," although this finding could have been skewed by others who had already "successfully returned, reestablished their livelihoods, and do not consider relocation" (219). Although the surveyed group exhibited a strong affinity for coastal living, some respondents expressed concern about flood insurance rate increases, which could make relocation necessary. Displaced families that wished to return home were impeded by the time and expense associated with rebuilding their homes.

Among those that chose to relocate are residents that sold their homes at a cheap price, decided to pay to have their homes torn down, or participated in a state voluntary buyout program, such as the NY Rising Buyout and Acquisition Program or the New Jersey Blue Acres Program (Baussan \& Peterson, 2015). In the buyout alternative, governments normally purchased properties at a pre-flood market value and tore them down to restore the land to its natural state or convert it to a flood buffer zone to prevent similar house destructions in the future.

\subsection{Distilling Factors Affecting Return}

Based on a review of literature (Note 2) from both disasters, there appear to be five major factors influencing peoples' long-term decisions regarding whether they return home, relocate, or remain in limbo:

- Habitability of homes, including the degree of vulnerability to future damage;

- Access to affordable housing;

- Financial burdens associated with moving back or rebuilding, including access to and effectiveness of government-funded home rebuilding programs;

- Restoration of and access to public services and facilities; and

- Sense of place and identity.

These factors do not affect all people displaced by a disaster equally; socio-economic characteristics may make some people or groups more vulnerable, reduce access to services and aid, and may limit return or relocation options (Bukvic et al., 2015). While not as dominant, other common factors include: fear of future disasters, stress attributed to rebuilding and recovery processes, and loss of employment.

\section{Policy Responses to Post-Disaster Return Challenges}

Governments employ a vast array of policies that directly and indirectly affect where people decide to live, such as municipal zoning laws and development regulations, tax policies that favor homeownership, and subsidized housing assistance for low-income households. Following a disaster, as shown by the surveys reviewed above, policies can influence whether displaced individuals and families decide to return or relocate; they can also affect which people or groups are more likely to end up in limbo for long periods of time. 


\section{Macrothink}

Journal of Asian Development

ISSN 2377-9594 2017, Vol. 3, No. 1

As noted above, surveys and studies of people affected by Hurricanes Katrina and Sandy have shown the impact of housing issues, public services shortages, financial constraints, loss of employment, and other individual or family concerns on how displaced people make long-term post-disaster decisions to return or relocate.

\subsection{Classifying Policy Goals}

In examining the policies related to post-disaster return or relocation following Hurricane Katrina and Superstorm Sandy, we consider two dimensions of policy goals for post-disaster return (Figure 1). The first is geographic: whether to actively encourage, discourage, or prohibit return to a specific area (or take a neutral stance). On one end of the spectrum are policies that encourage everyone who was displaced by the disaster to return to their previous homes and communities, rebuilding as necessary. On the other end are policies discouraging or even prohibiting return (e.g., by prohibiting rebuilding of pre-disaster homes in specific areas). This may be because policymakers have decided that such areas are unsafe, vulnerable to future disasters, or not suitable for environmentally sustainable development. In the aftermath of Hurricane Katrina, one author described the question of whether to rebuild the parts of the city prone to future flooding as a dichotomy between "maintainers" and "abandonists" (Campanella, 2008).

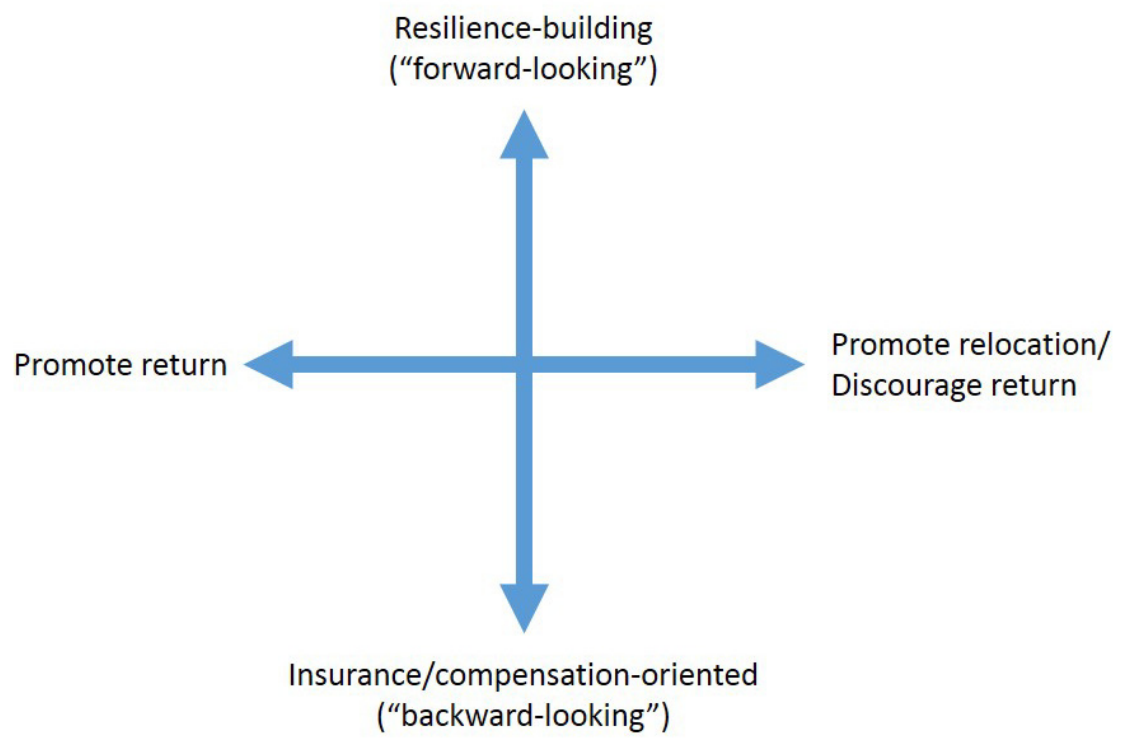

Figure 1. Spectrum of policy goals related to post-disaster return

The second policy dimension represents a consideration of the social goal in supporting people displaced by disasters. On one end is the goal of compensating displaced persons for what they have lost, returning them (as best as possible) to the state they were in before the disaster. In other words, the policy response may be insurance-like, geared toward making an area or group of people whole. This type of policy socializes costs after a disaster to help those who had significant losses rebuild and go back to "life as normal" prior to the disaster. 


\section{Macrothink}

Examples of insurance-like policies designed to promote return would include aid for rebuilding housing that can only be used for reconstruction on previously inhabited land. "Backward-looking" policies could be agnostic as to return or relocation, or could discourage return if the compensation only accounts for direct property losses and does not incorporate concerns about employment, infrastructure, or public services.

Alternatively, the long-term goal may be a broader, resilience-oriented goal. This would mean using public resources following a disaster to strengthen communities' resilience to future catastrophes. In the upper-left quadrant of the figure, policies are based on the goal of promoting return, in the sense of "building back better" with incentives or requirements for disaster-sensitive building standards and community planning. In the upper-right quadrant, by contrast, some "resilience-building" policies would not necessarily mean rebuilding in exactly the same place or configuration, and in some circumstances, may mean discouraging return of displaced residents where resilient reconstruction is not feasible. This type of goal also focuses on promoting economic growth and recovery in a depressed area, responding to problems that predate the disaster, when possible, in order to better prepare a community for future events.

Once the policy goal is agreed upon, specific policy tools and choices should take into account practical concerns with achieving these goals, as well as the direct and indirect socioeconomic consequences. For example, compensation for rebuilding in flood-prone areas can create moral hazard concerns that incentivize irrational risks or unsafe choices (Mankiw, 2008). Compensation, redistribution, or resilience-building policies may fail to reach the poorest of the poor, or may result in disparate impacts on racial minorities or other marginalized groups.

In reality, policies may not always reflect or achieve these goals for at least two reasons. First, conflicting priorities among decision-makers or lack of adequate planning before, during, and after a disaster may mean that the long-term policies are not chosen coherently or in a holistic manner. Second, financial, political, social, legal, or institutional constraints apply and may preclude some policy choices that would be better suited to meeting long-term goals.

\subsection{Policy Tools Used After Katrina and Sandy}

In the years following Hurricane Katrina and Superstorm Sandy, federal, state, and local governments have used a range of policies that address community rebuilding or return. Illustrative examples of these policies include tax exemptions and incentives, buyouts, changes to building codes, and changes to the National Flood Insurance Program.

\subsubsection{Tax policies}

After Hurricane Katrina, Congress passed tax-related legislation aimed at assisting victims of the disaster, including the Katrina Emergency Tax Relief Act of 2005 (KETRA) (Note 3) and the Gulf Opportunity Zone Act of 2005 (GOZA) (Note 4). These were modeled after the tax bills passed for New York City after the 9/11 terrorist attack (Stead, 2006). This body of legislation affected taxes in a number of different ways. For example, it increased the degree to which taxpayers could offset their taxable income by claiming disaster losses. It also 
allowed taxpayers to claim the Earned Income Tax Credit based on income from 2004 (the year before the storm) if it was more advantageous - essentially preserving the benefit of the tax credit for low-income workers even if their usual opportunities for wages had been disrupted (Internal Revenue Service, 2006). Additional tax exemptions and tax incentives were designed to encourage rebuilding of homes, infrastructure, and services, and to encourage employers to increase hiring (through wage-related incentives).

These tax policies can be classified as compensation-oriented policies as they mitigate financial losses, but do not appear on their face to be designed either to promote or inhibit return. Some scholars have misgivings about using tax incentives as disaster relief policies because of their potential distributional impacts. Although tax code changes may be relatively easy policy solutions to implement, they tend not to provide relief to lower-income classes (other than the EITC example above), which means that money may be better spent or allocated in other ways (Stead, 2006).

\subsubsection{Buyouts}

Policymakers and other stakeholders may decide after a disaster to discourage or even prohibit return, due to concerns about public safety, environmental protection, or otherwise. In such cases, the strongest tool that can be used is outright prohibition of rebuilding and demolition of existing structures. Following Katrina and Sandy, policymakers discussed possibilities for buying out landowners in vulnerable areas.

After Superstorm Sandy, responses by the states of New York and New Jersey showed starkly divergent priorities with regard to assistance for homeowners. In January 2013, Congress appropriated US\$60 billion in disaster relief aid, including $\$ 16$ billion for a Community Development Fund administered by HUD. (Note 5) New Jersey's governor, Chris Christie, announced a plan to use portions of this money to compensate affected homeowners to repair and rebuild existing flood-damaged houses (Farber, Chen, Verchick \& Sun, 2015). New York, on the other hand, developed a voluntary buyout plan, offering homeowners in high-risk areas 100 percent of the pre-storm fair market value of their homes, with a 10 percent incentive bonus for "enhanced buyout areas" and an additional 5 percent incentive for residents who relocate to a new house within the same county (Farber et al., 2015; NY Governor's Office of Storm Recovery, 2015). (Note 6) Homes that are purchased through this program are demolished, and the sites are returned to marshlands.

Importantly, the aforementioned rebuilding or buyout programs in New York and New Jersey are voluntary. U.S. government restrictions in granting the money limit states' ability to use eminent domain to compel residents to sell their property, even in high-risk areas. (Note 7)

\subsubsection{Changing Building Codes}

In the United States, states (and in many cases, local governments) regulate the construction of buildings in order to meet various standards, including those related to safety. Standardized building codes, developed by the International Code Council, are applied to promote safety generally, as well as to prevent harm or damage during specific events, such as fires, earthquakes, tornados, and floods (International Code Council, 2016). Such codes are 


\section{MInstitute Macrothink $_{\text {Int }}$}

often tailored to match the relevant risks and circumstances in a given geographic area or jurisdiction. Following Hurricane Katrina, a number of states and local governments pushed for new or revised codes.

Building code changes - applying stricter constraints on how a home can be built in a disaster-prone area-generally focus on increasing resilience by mitigating future risk. Updating building codes can be a policy for promoting return in a more disaster-resilient manner. However, if the changes are seen as too stringent, making compliance too expensive or time-consuming, they could be criticized as "red tape" (as was the case after Superstorm Sandy, discussed above) and may end up prolonging decisions or ultimately favoring relocation.

\subsubsection{National Flood Insurance Program Revisions}

The National Flood Insurance Program (NFIP) was established in 1968, with the goal of providing an insurance system for property owners in flood-prone areas with gaps in the availability of private insurance. Participation in the NFIP is conditioned on compliance with floodplain management regulations implemented by states and local communities (FEMA, 2002). Flood insurance plans under the NFIP were originally optional for property owners. However, since 1973, NFIP plans in flood-risk areas (referred to as Special Flood Hazard Areas or SFHAs) are required in order to secure federally-backed mortgages or to use federal loans or grants for construction in NFIP-participating communities - effectively making the program mandatory in most cases (FEMA, 2002). FEMA is responsible for developing flood hazard maps in connection with the NFIP, using a 100-year flood (i.e., a flood level with a 1 percent likelihood of occurring in any given year) as the standard. Homes built after a map is set or updated are assessed actuarial NFIP rates (accounting for total estimated risk), while existing buildings are grandfathered in with effectively subsidized rates (FEMA, 2002).

Although some level of government subsidization of flood risk was expected, by 2014, the NFIP was US\$24 billion in debt, nearly all from two disasters: $\$ 17.5$ billion from Hurricane Katrina, and $\$ 6.25$ billion from Superstorm Sandy (FEMA, 2014). Critics of the program have argued that it is financially unsustainable and encourages people to return, remain, and rebuild in unsafe areas-leaving them open to the next disaster (U.S. Government Accountability Office, 2015, 385-91; Collins \& Akabas, 2014). In July 2012, several months before Sandy, and after years of debate, Congress enacted the Biggert-Waters Flood Insurance Reform Act of 2012 (Pub. L. 112-141, 126 Stat. 405, 916), designed to phase out the grandfathering provisions and bring NFIP policies in line with actuarial risk - a move that would eventually encourage retreat from the most flood-prone areas and coastlines.

However, the public backlash to flood insurance reform was swift and powerful. Two years later, the Homeowner Flood Insurance Affordability Act of 2014 (Pub. L. 113-89, 128 Stat. 1020) was passed with the support of politicians from disaster-affected states, whose constituents would have seen rising premium costs under the program. The 2014 Act repealed or indefinitely delayed the main elements of the 2012 reform, including the elimination of grandfathered-in insurance premiums (Knowles, 2014). 


\section{Observations: Challenges and Lessons for Policy on Post-Disaster Return}

Policymakers have a range of choices in developing approaches for long-term return after major disasters. These policies - many of which were pursued after Hurricane Katrina and Superstorm Sandy - range from strongly discouraging return to specific disaster-affected areas (e.g., buyouts) to promoting the rebuilding of homes and of communities (e.g., insurance payments, tax incentives for reconstruction, and, to an extent, bonus payments in buyout programs to favor nearby relocation when return to an exact site is disfavored). Connecting these policies with the factors that most strongly influence displaced individuals' could allow policymakers to identify where improvements can be made to more effectively achieve their objectives for post-disaster return. However, it is also critical for policymakers to recognize the significant ways in which policy instruments are limited-financially, politically, and, in some instances, constitutionally-in developing appropriate measures to employ following a disaster.

\subsection{Challenges and Policy Limitations}

Financial, political, and constitutional limitations on post-disaster return migration policy are interconnected in various ways. For example, financial constraints limit the extent to which buyout programs may be offered to encourage relocation. Political and social limitations can affect a government's ability to overcome those financial constraints through raising taxes or more extensive government borrowing. Political limitations may also appear if groups of citizens who are not offered the buyout (or are offered it on less favorable terms) view the program as unfair and decide to oppose it. Under the U.S. Constitution, private property cannot be taken for public use (such as the maintenance of development-free buffer zones in vulnerable areas) without payment of just compensation, meaning that such efforts will be limited by the government's financial capacity to pay for them.

Public perceptions may run against governments, as a result of these limitations, as communities suffer from "excessive policy demand" (Ingram \& Mann, 1980). Expectations for policies and programs may not be reasonable because governments have finite financial and human resources at their disposal, and are also limited by concerns of political feasibility. When solutions are proposed that would be effective but are outside cultural and political norms, "such as forced evacuations or forced expropriation of land in hazardous areas," policy goals are unlikely to be realized if the tools for getting there "are simply incongruent with ... political culture and the expectations of most citizens" (Birkland \& Waterman, 2008, 708). Approaches that are seen as too heavy-handed or that conflict with other priorities may engender political backlash, as in the case of changes to the National Flood Insurance Program-significant reform was enacted with the Biggert-Waters Act of 2012, only to be watered down two years later.

\subsection{Lessons: Strategic Planning and Targeted Policies}

With these limitations in mind, it is important for policymakers to make decisions early on about the objectives - whether, to what extent, and where post-disaster return of displaced people should be promoted - so that the most effective policies for achieving those objectives 
can be pursued. For areas prone to recurring disasters, especially, these objectives should be part of long-term planning processes in order to enhance cities' and communities' resilience.

For decision-makers, it is equally important to develop an understanding of the critical factors that affect displaced people's decisions about whether to return, so as to best align policy responses to the unique context and increase their rate of effectiveness. As described earlier, a review of the literature on return after Katrina and Sandy suggests five major factors affecting individual or household decisions regarding whether and how to return. Those factors relate to habitability of pre-disaster homes, housing affordability, other financial burdens, condition of public services and facilities, and people's sense of place and identity.

Although the examples discussed in this article - tax incentives, buyouts, changes to building codes, and flood insurance reform efforts - do not cover the full range of policies adopted after Hurricane Katrina and Superstorm Sandy, they suggest some pathways for improving policy. While considerable attention has focused on policies affecting homeowners whose primary residence was damaged, destroyed, or lies in an area prone to future disasters, the commonly-cited policy examples have been less attentive to concerns of housing affordability (including for renters) or to the need for functioning public services and facilities. After Katrina, there was an inadequate response to address "secondary damage" along the Gulf Coast - to hospitals, schools, and other "elements of public infrastructure" (Farber, Chen, Verchick \& Sun, 2010, 209). Such response, though, should not be overlooked, as availability of those public services is a critical factor affecting decisions whether to return.

With regard to housing availability and habitability, tax policies can be designed to encourage rebuilding. However, tax relief for individual households has a delayed impact (felt at the time of filing tax returns or obtaining a refund) and is less likely to directly reach renters or poor residents. Lack of rebuilding of public housing, as was the case in New Orleans after Hurricane Katrina (Bliss, 2015), became in itself a policy decision and placed limits on opportunities for return. Additional tax policies can be tailored to try and promote other policy goals, such as wage-related tax incentives designed to boost employment. Although tax policies may be relatively uncomplicated to implement, policymakers should ensure that the policies are equitable and appropriately targeted to fulfill objectives for return.

Buyouts are an effective, but expensive tool for inhibiting return to pre-disaster locations, although the benefits of such programs may depend on the percentage of people electing to participate and leave a specific area. Flood insurance changes form a comprehensive resilience-based policy that also inhibits return to highest-risk pre-disaster locations. However, political limitations after Superstorm Sandy have demonstrated how major reform of development arrangements can be difficult to accomplish. As for changes to building codes, a point for further research may be the extent to which updated codes affect homeowner and homebuyer attitudes about whether a house feels "safe" from the potential for future disasters.

\section{Conclusion}

Disasters can disrupt communities not only via immediate impacts, but also in the longer 
term, as people who have been displaced struggle with their decisions and abilities to return, relocate, or remain uprooted in the years that follow. Studies after Hurricane Katrina and Superstorm Sandy show that housing habitability, availability, and affordability is of utmost concern to displaced people making decisions on post-disaster return, and that other factors are important as well: restoration of public services, sense of place and identity, and financial burdens. Policymakers may set site-specific objectives about whether to encourage or inhibit return to a city, community, or neighborhood after a disaster. An understanding of the relevant factors for displaced people can help allow for targeted policies to focus on supporting communities and individuals in working toward meeting those objectives. Policy objectives that are most responsive to the concerns of disaster-affected populations not only help families to resume their normal lives more quickly, but can also help guarantee more sustainable and long-term solutions.

\section{Acknowledgements}

The authors wish to thank Sofia Yazykova and Julia Forgie for their comments and suggestions toward improving this article.

\section{References}

Amnesty International. (2010). Un-natural disaster. Human rights in the Gulf Coast. Retrieved from http://www.amnestyusa.org/sites/default/files/pdfs/unnaturaldisaster.pdf

Barron, J., Lipton, E., \& Rivera, R. (2012, November 5). With \$200 million in U.S. housing aid, officials begin relocating the displaced. The New York Times. Retrieved from http://www.nytimes.com/2012/11/06/nyregion/housing-relocation-begins-after-hurricane-san dy.html

Baussan, D., \& Peterson, M. (2015). Lessons from the storm: Climate displacement three years after Hurricane Sandy. Center for American Progress. Retrieved from https://cdn.americanprogress.org/wp-content/uploads/2015/10/27135335/SandyClimateDispl acement-summary.pdf

Birkland, T., \& Waterman, S. (2008). Is Federalism the reason for policy failure in Hurricane Katrina?” Publius, 38, 692. https://doi.org/ 10.1093/publius/pjn020

Bliss, L. (2015, August 25). 10 years later, there's so much we don't know about where Katrina survivors ended up. CityLab. Retrieved from http://www.citylab.com/politics/2015/08/10years-later-theres-still-a-lot-we-dont-know-about-where-katrina-survivors-ended-up/401216/

Bukvic, A., Smith, A., \& Zhang, A. (2015). Evaluating drivers of coastal relocation in Hurricane Sandy affected communities. International Journal of Disaster Risk Reduction, 13, 215-228. https://doi.org/10.1016/j.ijdrr.2015.06.008

Campanella, R. (2008). Bienville's Dilemma: A Historical Geography of New Orleans. Lafayette: Center for Louisiana Studies, University of Louisiana at Lafayette.

Chamlee-Wright, E., \& Storr, V.H. (2009). “There's no place like New Orleans": Sense of place and community recovery in the Ninth Ward after Hurricane Katrina. Journal of Urban 
Affairs, 31(5), 615-634. https://doi.org/ 10.1111/j.1467-9906.2009.00479.x

Collins, B, \& Akabas, S. (2014). "The National Flood Insurance Program still requires reform." Bipartisan Policy Center. Retrieved from http://bipartisanpolicy.org/blog/nationalflood-insurance-program-still-requires-reform/

Dart, T. (2014, January 27). New Orleans: houses can be rebuilt, but can trust in central government? The Guardian. Retrieved from http://www.theguardian.com/cities/2014/jan/27/ new-orleans-houses-rebuilt-trust-government-hurricane-katrina

Dewan, S. (2007, July 12). Road to new life after Katrina is closed to many. The New York Times. Retrieved from http://www.nytimes.com/2007/07/12/us/nationalspecial/12exile.html? pagewanted $=$ all

Falk, W., Hunt, M. O., \& Hunt, L. L. (2006). Hurricane Katrina and New Orleanian's sense of place: Return and reconstitution or "Gone With the Wind"?" Du Bois Review, 3, 115-128. https://doi.org/ 10.10170S1742058X06060036

Farber, D. A., Chen, J., Verchick, R., \& Sun, L. (2015). Disaster law and policy (3rd ed.). New York, NY: Wolters Kluwer Law \& Business.

Farber, D. A., Chen, J., Verchick, R., \& Sun, L. (2010). Disaster law and policy (2nd ed.). New York, NY: Wolters Kluwer Law \& Business.

FEMA. (2014, July 23). Statement of Craig Fugate [FEMA Administrator] before the U.S. Senate Committee on Appropriations, Subcommittee on Homeland Security.

FEMA. (2002). National Flood Insurance Program: Program Description. Retrieved from https:/www.fema.gov/media-library-data/20130726-1447-20490-2156/nfipdescrip_1_.pdf

FEMA. (2006a). By the numbers - one year later. Retrieved from http://www.fema.gov/ news-release/2006/08/22/numbers-one-year-later

FEMA. (2006b). Hurricane Katrina in the Gulf Coast. Mitigation assessment team report. Retrieved from https://www.fema.gov/media-library-data/20130726-1520-20490-4067/ 549 _cvr_toc.pdf

Finger, D. (2011). Public housing in New Orleans post Katrina: The struggle for housing as a human right. Review of Black Political Economy, 38, 327-337.

Fussell, E., Sastry, N., \& VanLandingham, M. (2010). Race, socioeconomic status, and return migration to New Orleans after Hurricane Katrina. Population Environment, 31, 20-42. https://doi.org/10.1007/s11111-009-0092-2.

Geaghan, K. A. (2011). Forced to move: An analysis of Hurricane Katrina movers. SEHSD Working Paper Number 2011 - 17, U.S. Census Bureau. Retrieved from https://www.census.gov/ library/working-papers/2011/demo/SEHSD-WP2011-17.html

Groen, J. A., \& Polivka, A. E. (2008). Hurricane Katrina evacuees: Who they are, where they are, and how they are faring. U.S. Bureau of Labor Statistics. Retrieved from 
http://www.bls.gov/opub/mlr/2008/03/art3full.pdf

Groen, J. A., \& Polivka, A. E. (2010). Going home after Hurricane Katrina: Determinants of return migration and changes in affected areas. Demography, 47, 821-844. https://doi.org/10.1007/BF03214587

Hanna, M., \& Seidman, A. (2014, October 29). Hurricane Sandy: Thousands await aid to rebuild in New Jersey. Emergency Management. Retrieved from http://www.emergencymgmt.com/disaster/Hurricane-Sandy-Thousands-Await-Aid-RebuildNew-Jersey.html

Henry, J. (2013). Return or relocate? An inductive analysis of decision-making in a disaster." Disasters, 37, 293-316. https://doi.org/10.1111/j.1467-7717.2012.01303.x

Ingram, H. M., \& Mann D. E. (1980). Policy failure: An issue deserving attention. In H.M. Ingram \& D.E. Mann (Eds.), Why policies succeed or fail (pp. 11-32). Beverley Hills, CA: Sage Publications.

Internal Displacement Monitoring Centre. (2013). Global estimates 2012: People displaced by disasters. Retrieved from http://www.internal-displacement.org/assets/publications/2013/ 2012-global-estimates-corporate-en.pdf

Internal Displacement Monitoring Centre. (2015). Global estimates 2015: People displaced by disasters. Retrieved from http://reliefweb.int/sites/reliefweb.int/files/resources/20150713global-estimates-2015-en.pdf

Internal Revenue Service. (2006). Tax law changes related to Hurricanes Katrina, Rita and Wilma. Retrieved from https://www.irs.gov/uac/tax-law-changes-related-to-hurricaneskatrina-rita-and-wilma

International Code Council. About ICC. Retrieved September 19, 2016 from http://www.iccsafe.org/about-icc/overview/about-international-code-council/

Kalet, H. (2013, June26). Renters: Hurricane Sandy's invisible victims. NJ Spotlight. Retrieved from http://www.njspotlight.com/stories/13/06/25/renters-hurricane-sandys-invisible-victims/

Kamel, N. (2012). Social marginalisation, federal assistance and repopulation patterns in the New Orleans metropolitan area following Hurricane Katrina. Urban Studies, 49, 3211-3231. https://doi.org/ 10.1177/0042098011433490

Knowles, S. G. (2014, March 23). Flood zone foolishness. Slate. Retrieved from http://www.slate.com/articles/health_and_science/science/2014/03/biggert_waters_and_nfip_ flood_insurance_should_be_strengthened.html

Kusisto, L., \& Dawsey, J. (2014, June 17). Many displaced by Superstorm Sandy still wait for housing help. The Wall Street Journal. Retrieved from http:/www.wsj.com/articles/ many-displaced-by-superstorm-sandy-still-wait-for-housing-help-1403060886

Landry, C. E., Bin, O., Hindsley, P., Whitehead, J., \& Wilson, K. (2007). Going home: 
Evacuation-migration decisions of Hurricane Katrina survivors. Southern Economic Journal, 74, 326-343. https://doi.org/10.2307/20111970

Lewis, R. (2013, August 29). Eight years after Hurricane Katrina, many evacuees yet to return. Al Jazeera America. Retrieved from http://america.aljazeera.com/articles/2013/8/29/ eight-years-afterkatrinalowincomeevacueeshaveyettoreturn.html

Luedekke, K. (2015, May 11). Slowly rebuilding after Sandy, but thousands still displaced while working with N.J. program. North Jersey. Retrieved from http://www.northjersey.com/ news/slowly-rebuilding-after-sandy-but-thousands-still-displaced-while-working-with-n-j-pro gram-1.1330907?page $=2$

Mankiw, N. G. (2008). Principles of Economics ( $5^{\text {th }}$ ed.). Mason, OH: Cengage Learning.

McClendon, R. (2015, June 26). With thousands still displaced, advocates call for better road home rules. Nola. Retrieved from http:/www.nola.com/politics/index.ssf/2015/06/with thousands_still_displaced.html

McGeehan, P., \& Palmer, G. (2013, December 6). Displaced by Hurricane Sandy, and living in limbo. The New York Times. Retrieved from http://www.nytimes.com/2013/12/07/ nyregion/displaced-by-hurricane-sandy-and-living-in-limbo-instead-of-at-home.html

Morrice, S. (2013). Heartache and Hurricane Katrina: Recognising the influence of emotion in post-disaster return decisions. Area, 45, 33-39. https://doi.org/ 10.1111/j.1475-4762.2012.01121.x

National Centers for Environmental Information. Billion-dollar weather and climate disasters: Table of events. Retrieved September 19, 2016 from https:/www.ncdc.noaa.gov/billions/ events

New York Governor's Office of Storm Recovery. (2015). NY Rising Buyout and Acquisition Program Policy Manual (Version 3.0)

Parry, W. (2013, April 28). After Hurricane Sandy, homeless still number in the thousands in New York, New Jersey. The Huffington Post. Retrieved from http://www.huffingtonpost.com/ 2013/04/28/hurricane-sandy-homeless-homelessness_n_3174444.html

Paxson, C., \& Rouse, C.E. (2008). Returning to New Orleans after Hurricane Katrina. American Economic Review, 98, 38-42. https://doi.org/10.1257/aer.98.2.38

Plyer, A. (2016, August 26). Facts for features: Katrina impact. The Data Center. Retrieved from http://www.datacenterresearch.org/data-resources/katrina/facts-for-impact/

Robertson, C. (2011, February 3). Smaller New Orleans after Katrina, census shows. The New York Times. Retrieved from http://www.nytimes.com/2011/02/04/us/04census.html? $\mathrm{r}=0$

Sastry, N. (2009). Displaced New Orleans residents in the aftermath of Hurricane Katrina: Results from a pilot survey. Organization and Environment, 22, 395-409. https://doi.org/10.1177/1086026609347183 
Sastry, N., \& Gregory, J. (2014). The location of displaced New Orleans residents in the year after Hurricane Katrina. Demography, 753-775. https://doi.org/10.1007/s13524-014-0284-y

Shrinath, N., Mack, V., \& Plyer, A. (2014, October 16). Who lives in New Orleans and metro parishes now? The Data Center. Retrieved from http://www.datacenterresearch.org/dataresources/ who-lives-in-new-orleans-now/

Stead, M. M. (2006). Implementing disaster relief through tax expenditures: An assessment of the Katrina emergency tax relief measures. 81 N.Y.U. L. Rev., 2158, 2159-60.

Fair Share Housing Center, Latino Action Network and NAACP New Jersey State Conference. (2015). The State of Sandy Recovery (Second Annual Report). Retrieved from http://fairsharehousing.org/images/uploads/State_of_Sandy_English_2015.pdf

Tilove, J. (2010, August 24). Five years after Hurricane Katrina, 100,000 New Orleanians have yet to return. The Times-Picayune. Retrieved from http://www.nola.com/katrina/index.ssf/ 2010/08/five_years_after_hurricane_kat.html

U.S. Census Bureau. Population Estimates. Retrieved from https://www.census.gov/popest/ index.html

U.S. Government Accountability Office. (2015). High-Risk Series: An Update. Retrieved from http://www.gao.gov/assets/670/668415.pdf

Vigdor, J. (2008). The economic aftermath of Hurricane Katrina. Journal of Economic Perspectives, 22, 135-154. https://doi.org/ 10.1257/jep.22.4.135

Winerip, M. (2013, October 28). After hurricanes, the 'road home,' the long way. The New York Times. Retrieved from http://www.nytimes.com/2013/10/28/booming/after-hurricanes -the-road-home-the-long-way.html

\section{Glossary}

FEMA: U.S. Federal Emergency Management Agency

\section{Notes}

Note 1. Some 70,000 New Orleans residents remained in the city, either by personal choice, or because they lacked a feasible way to evacuate.

Note 2. There are more scholarly sources published on the factors affecting return of populations displaced by Hurricane Katrina than there are of Superstorm Sandy. Most information on Sandy-affected populations has been gathered from major media sources.

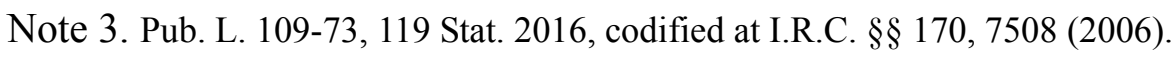

Note 4. Pub. L. 109-135, 119 Stat. 2577, codified at I.R.C. $\S \S 38,54,1400$ N (2006).

Note 5. This fund was created by the Disaster Relief Appropriations Act of 2013, Pub. L. 113-2, 127 Stat. 4, 36 (Jan. 29, 2013). 


\section{Macrothink}

Journal of Asian Development

ISSN 2377-9594 2017, Vol. 3, No. 1

Note 6. For residents of New York City, which covers multiple counties, the 5 percent "return" bonus applied across the entire city.

Note 7. Although there is no statutory prohibition on eminent domain in such circumstances, federal appropriations legislation restricts the use of eminent domain in programs funded by federal money and distributed by the Department of Housing and Urban Development (including funds that pass through state or local governments). See, e.g., Consolidated Appropriations Act of 2016, Pub. L. 114-113, 129 Stat. 2242, 2905 (Dec. 18, 2015) (covering appropriations to HUD for the 2016 fiscal year).

\section{Copyright Disclaimer}

Copyright for this article is retained by the author(s), with first publication rights granted to the journal.

This is an open-access article distributed under the terms and conditions of the Creative Commons Attribution license (http://creativecommons.org/licenses/by/3.0/). 